African Crop Science Journal by African Crop Science Society is licensed under a Creative Commons Attribution 3.0 Uganda License. Based on a work at www.ajol.info/ and www.bioline.org.br/cs DOI: http://dx.doi.org/10.4314/acsj.v24i4.4

\title{
EXPLOITATION OF GENETIC POTENTIAL OF SWEETPOTATO FOR END-USER TRAITS IMPROVEMENT
}

\author{
E. BAAFI, K. OFORI ${ }^{1}$, E. T. BLAY ${ }^{1}$, V. E. GRACEN ${ }^{1}$, J. MANU-ADUENING and E. E. CAREY ${ }^{2}$ \\ CSIR-Crops Research Institute, P. O. Box 3785, Kumasi, Ghana \\ ${ }^{1}$ West Africa Centre for Crop Improvement (WACCI), University of Ghana, PMB LG 30, Legon, Ghana \\ ${ }^{2}$ International Potato Centre (CIP), \% CSIR-Crops Research Institute, P. O. Box 3785, Kumasi, Ghana
}

Corresponding author: e.baafi@gmail.com

(Received 31 May, 2015; accepted 3 November, 2016)

\begin{abstract}
Sweetpotato (Ipomoea batatas Lam) is a staple food globally, but it has remained underutilised resource in Ghana due to lack of consumer preferred cultivars. There is the need to develop staple-type sweetpotato cultivars which are preferred by consumers to increase sweetpotato use as a food security, health and industrial crop commodity in Ghana. This study was conducted to evaluate the breeding potential of sweetpotato germplasm for the development of farmer and consumer preferred varieties in Ghana. A total of 115 sweetpotato accessions were evaluated for genetic variability. Significant $(\mathrm{P}<0.01)$ differences were observed indicating genetic diversity. $\mathrm{G} \mathrm{x}$ E was significant for all traits, except dry matter, sucrose, total sugar, and starch content. Phenotypic Coefficient of Variation (PCV) ranged from $4.78 \%$ for starch content to $63.40 \%$ for marketable root weight. Genotypic Coefficient of Variation (GCV) ranged from $4.07 \%$ for starch content to $55.35 \%$ for marketable root weight. Broad-sense heritability estimates varied from medium (0.61) to high $(0.90)$ for all the traits, except for sucrose content. Predicted improvement over the means is 10 up to $105 \%$ for all traits, except starch (7.13\%). This indicates sufficient useful genetic variation prospect which could be used to provide substantial improvement through selection of superior genotypes. The strong positive genetic association between dry matter and starch $(r=0.71)$, and strong negative relationship for sugar and dry matter $(r=-0.77)$ and starch content $(r=-0.99)$ indicates the possibility of developing non-sweet high dry matter sweetpotatoes, which are the preferred varieties in Ghana.
\end{abstract}

Key Words: Beta-carotene, genotypic coefficient of variation, heritability, Ipomoea batatas, non-sweet sweetpotato, phenotypic coefficient of variation

\section{RÉSUMÉ}

La patate douce (Ipomoea batatas Lam) est un aliment de base à l'échelle mondiale, mais c'est une ressource sousutilisée au Ghana en raison du manque de cultivars préféré par les consommateurs. Il est nécessaire de développer des cultivars de patate douce de type de base qui sont préférés par les consommateurs pour augmenter l'utilisation de la patate douce comme la culture de la sécurité alimentaire, la culture de santé et le produit industriel au Ghana. Cette étude a été menée pour évaluer le potentiel du matériel génétique du germeplasme de la patate douce pour le développement des variétés préférées par les agriculteurs et les consommateurs au Ghana. Un total de 115 germeplasmes de patate douce ont été évalués pour la variabilité génétique. Des différences significatives de $(\mathrm{P}$ $<0,01)$ ont été observées indiquant la diversité génétique. G x E était important pour tous les traits, à l'exception de matière sèche, le saccharose, le sucre total et la teneur en amidon. Coefficient Phénotypique de variation (CPV) variait de $4,78 \%$ pour la teneur en amidon à $63,40 \%$ pour le poids de racine commercialisables. Coefficient génotypique de variation $(\mathrm{CGV})$ variait de $4,07 \%$ pour la teneur en amidon à $55,35 \%$ pour le poids de racine 
commercialisables. Coefficient génotypique de variation (CGV) variait de 7,60\% pour la teneur en matière sèche à $55,35 \%$ pour le poids de racine commercialisables. Estimations de l'héritabilité au sens large variat de $(0,61)$ moyen à $(0,90)$ haut pour tous les traits, sauf pour la teneur en saccharose. L'amélioration prédite sur le moyen est de 10 à 105\% pour tous les traits, à l'exception de l'amidon (7,13\%). Cela indique suffisamment la perspective de la variation génétique utile qui pourrait être utilisé pour fournir une amélioration substantielle par la sélection de génotypes supérieurs. Une forte relation génétique positive entre la matière sèche et l'amidon $(r=0,71)$, et une forte relation négative pour le sucre et la matière sèche $(r=-0,77)$ et la teneur en amidon $(r=-0,99)$ indiquent la possibilité de développer la patate douce qui est non sucrée, haute de matière sèche et qui sont les variétés préférées au Ghana.

Mots Clés: Bêta-carotène, coefficient génotypique de variation, héritabilité, Ipomoea batatas, patate douce nonsucré, coefficient phénotypique de variation

\section{INTRODUCTION}

Sweetpotato (Ipomoea batatas Lam) is a dicotyledonous plant of the botanical family Convolvulaceae (Watson and Dallwitz, 2000). It is one of the most important root crops in the world (Warammboi et al., 2011). Sweetpotato is a staple food for millions of people and the seventh most abundant crop globally (Bouvelle-Benjamin, 2007; Devi et al., 2014). The potential of sweetpotato in food security and global wellbeing has been well recognised (Van Hal, 2000; Lebot, 2010).

In spite of its great potential to alleviate food insecurity, malnutrition and poverty, it has remained an underutilised resource in Ghana. For instance, it is uncommon to find sweetpotato served in public places such as local restaurants, canteens and schools. Locally available varieties have very sweet taste (Missah and Kissiedu, 1994; Baafi et al., 2015), and recently introduced orange-fleshed genotypes which possess the precursor to combat vitamin A deficiency at relatively cheaper cost have low dry matter content, limiting their consumption as a staple food. There is a need to develop staple-type high beta-carotene and high dry matter content varieties to increase sweetpotato use as a food security, health and industrial crop commodity in Ghana.

Screening populations with high frequencies of favourable alleles can provide the best parents for breeding (Gasura et al., 2008). Knowledge on the genetic potential of the available germplasm is essential to find source(s) of variation for the end-user traits improvement. Information on the nature and magnitude of variability and heritability in a population owing to genetic and non-genetic factors is one of the prerequisites in any breeding programme (Kumar et al., 1985). There is knowledge gap on the genetic variability and breeding potential of sweetpotato for the end-user traits improvement in Ghana. The objective of this study was to assess the breeding potential of sweetpotato accessions in Ghana, for the development of non-sweet, high dry matter and high beta-carotene varieties through combination of desired traits into a common genetic background.

\section{MATERIALS AND METHODS}

This research was carried out at Fumesua (Forest ecozone) and Pokuase (Coastal Savannah ecozone) in the major and minor cropping seasons in 2011. The sweetpotato accessions used in the study are presented in Table 1 . The planting arrangement was one row per ridge, with a distance of $1 \mathrm{~m}$ between ridges. The length of a ridge was $3.6 \mathrm{~m}$ and within row planting space was $0.3 \mathrm{~m}$, giving a total of 12 plants per ridge. Randomised complete block design (RCBD) was used.

Data collection. Harvesting was done at three and half months after planting. The 10 central plants per row were harvested and were used for storage root yield assessment. Storage root yield data taken were total root yield and marketable root yield. In addition, harvest index was recorded as the ratio of the total root yield to total biomass. Thereafter, one large, one medium and one small storage root, were randomly selected for determination of the physico-chemical traits. 
TABLE 1. Description of 115 sweetpotato accessions collected and evaluated in the study

\begin{tabular}{|c|c|c|c|c|}
\hline \multirow{2}{*}{$\begin{array}{l}\text { Local accessions } \\
\text { CRIWAC 01-10 }\end{array}$} & \multirow{2}{*}{$\begin{array}{l}\text { Local improved varieties } \\
\text { SANTOMPONA }\end{array}$} & \multicolumn{2}{|c|}{ Accessions from NARS } & \multirow{2}{*}{$\begin{array}{l}\text { Accessions from CIP } \\
\text { CIP } 442903\end{array}$} \\
\hline & & TAG 03-019 & B-REGARD & \\
\hline CRIWAC 02-10 & FAARA & NS 001 & FIASO RED & CIP 442291 \\
\hline CRIWAC 03-10 & TEKSANTOM & OK 03-015 & TAG 03-030 & CIP 440069 \\
\hline CRIWAC 04-10 & OGYEFO & DOS 03-021 & GWERI & CIP 440390 \\
\hline CRIWAC 05-10 & OKUMKOM & CARROT C & BD 96-029 & CIP 442462 \\
\hline CRIWAC 06-10 & отоО & HUMBERCHERO & FREMA & CIP 442776 \\
\hline CRIWAC 07-10 & HISTARCH & B/FASO 002 & DOS 03-006 & CIP 440062 \\
\hline CRIWAC 08-10 & SAUTI & FA $10-026$ & NS 003 & CIP 442589 \\
\hline CRIWAC 09-10 & APOMUDEN & RESISTO & AAT 03-004 & CIP 442145 \\
\hline CRIWAC 10-10 & & CEMSA & OK 03-021 & CIP 442147 \\
\hline CRIWAC 11-10 & & 199062.1 & ВОТ 03-030 & CIP 440095 \\
\hline CRIWAC 12-10 & & OK 03-014 & OK 03-017 & CIP 441771 \\
\hline CRIWAC 13-10 & & JONATHAN & KAYIA WHITE & CIP 442901 \\
\hline CRIWAC 14-10 & & H-ASIATOR & UKEREWE & CIP 443016 \\
\hline CRIWAC 15-10 & & TANZANIA & OK 03-018 & CIP 440071 \\
\hline CRIWAC 16-10 & & NINGSHU 1 & & CIP 442896 \\
\hline CRIWAC $17-10$ & & SPK 004 & & CIP 442162 \\
\hline CRIWAC 18-10 & & $\mathrm{MOHC}$ & & CIP 442775 \\
\hline CRIWAC 19-10 & & ВОТ 03-028 & & CIP 443027 \\
\hline CRIWAC 20-10 & & BOT 03-020 & & CIP 443129 \\
\hline CRIWAC 21-10 & & J-ORANGE & & CIP 442264 \\
\hline CRIWAC 22-10 & & ВОТ 03-027 & & CIP 442654 \\
\hline CRIWAC 23-10 & & ADA 001 & & CIP 443035 \\
\hline CRIWAC 24-10 & & DOS 03-017 & & CIP 442913 \\
\hline CRIWAC 25-10 & & NAV 001 & & CIP 442237 \\
\hline CRIWAC 26-10 & & KEMB 37 & & CIP 443019 \\
\hline CRIWAC 27-10 & & AAT 03-025 & & CIP 442850 \\
\hline CRIWAC 28-10 & & B/FASO 001 & & \\
\hline CRIWAC 29-10 & & ZAMBEZI & & \\
\hline CRIWAC 30-10 & & ВОТ 03-020 & & \\
\hline CRIWAC 31-10 & & NASPOT 1 & & \\
\hline CRIWAC 32-10 & & AAT 03-017 & & \\
\hline
\end{tabular}

Storage roots selected were approximately $3 \mathrm{~cm}$ or more in diameter and without cracks, insect damage or rotten parts (Ekanayake et al., 1990). They were washed, peeled and cut into four equal parts longitudinally. Two opposite quarters of the peeled storage roots were sliced into pieces and $50 \mathrm{~g}$ fresh sample weighed into a polythene envelope. The fresh samples were frozen using deep-freezer after which it was freeze-dried for 72 hours using freeze-dryer. The dry weights of the freeze-dried samples were recorded. The freezedried samples were milled and used for the determination of all the physico-chemical traits except dry matter content using the near-infrared reflectance spectroscopy (NIRS) (Tumwegamire et al., 2011). The physico-chemical traits measured were beta-carotene, dry matter, fructose, glucose, sucrose, total sugar, starch, protein, iron and zinc content. Dry matter content was calculated after freeze drying as the ratio of the weight of the dry sample expressed as a percentage of the weight of the fresh sample. The laboratory work was carried out at the International Potato Centre (CIP) Fumesua, Ghana and Lima, Peru, respectively.

Data analysis. Data for 102 out of the 115 accessions were analysed because of lack of plants for some accessions. The analysis also excluded minor cropping season data for Pokuase 
because the experiment failed due to erratic rainfall. The data were subjected to Analysis of Variance (ANOVA) using GenStat statistical package (Genstat, 2007). To test the efficiency of RCBD for the analysis, relative efficiency (RE) of an Alpha Lattice design over RCBD was determined. The RE was determined as the ratio of the error means square of RCBD to that of the Alpha Lattice and the RE was not significant. RE is significant if the ratio is $>1$ and vice versa. Hence, RCBD was used to analyse the data employing the method of Steel and Torrie (1980).

Variance components were used to determine genotypic variance $(\mathrm{GV})$ and phenotypic variance (PV) as per Prasad et al. (1981) as follows:

Genotype x Location interaction variance

$\left(\sigma_{\mathrm{GL}}^{2}\right)=\left(\mathrm{MS}_{\mathrm{GL}}-\mathrm{MS}_{\mathrm{E}}\right) / \mathrm{r}$

Genotypic variance $\left(\sigma_{\mathrm{G}}^{2}\right)=\left(\mathrm{MS}_{\mathrm{G}}-\mathrm{MS}_{\mathrm{GL}}\right) / \mathrm{rl}=$

$\left(\sigma_{\mathrm{E}}^{2}+\mathrm{r} \sigma_{\mathrm{GL}}^{2}+\mathrm{rl} \sigma_{\mathrm{G}}^{2}-\sigma_{\mathrm{E}}^{2}+\mathrm{r} \sigma_{\mathrm{GL}}^{2}\right) / \mathrm{rl}$

Phenotypic variance $\left(\sigma_{\mathrm{P}}^{2}\right)=\sigma_{\mathrm{G}}^{2}+\sigma_{\mathrm{GL}}^{2} / 1+\sigma_{\mathrm{E}}^{2} / \mathrm{rl}=$

$\sigma_{\mathrm{G}}^{2}+\left(\left(\mathrm{MS}_{\mathrm{GL}}-\mathrm{MS}_{\mathrm{E}}\right) / \mathrm{r}\right) / 1+\sigma_{\mathrm{E}}^{2} / \mathrm{rl}$

Error variance $\left(\sigma_{\mathrm{E}}^{2}\right)=\mathrm{MS}_{\mathrm{E}}$

Where: MS = Means Square for a particular source of variation;

$\sigma_{\mathrm{G}}^{2}=$ Genotypic variance;

$\sigma_{\mathrm{GL}}^{2}=$ Genotype by location interaction variance;

$\sigma_{\mathrm{E}}^{2}=$ error variance;

$r=$ number of replications/location;

$1=$ number of locations or environments

Variance components were used to compute broad-sense heritability $\left(\mathrm{h}^{2}\right)$, Genotypic Coefficient of Variation (GCV), Phenotypic Coefficient of Variation (PCV) and Genetic
Advance (GA) (Burton, 1952; Johnson et al., 1955; Kumar et al., 1985), as presented below:

Heritability in broad - sense $\left(\mathrm{H}_{\mathrm{b}}^{2}\right)=\sigma_{\mathrm{G}^{2}} / \sigma_{\mathrm{P}}^{2}=$ $\sigma_{\mathrm{G}}^{2} /\left(\sigma_{\mathrm{G}}^{2}+\sigma_{\mathrm{GL}}^{2} / 1+\sigma_{\mathrm{E}}^{2} / \mathrm{rl}\right)$

Genotypic Coefficient of Variation $=\left(\sigma_{G} \times 100\right) / \mathrm{X}$

Phenotypic Coefficient of Variation $=\left(\sigma_{\mathrm{P}} \times 100\right) / \mathrm{X}$

Where: $\mathrm{X}$ is the grand mean of the trait.

Genetic Advance $(\mathrm{R})=\mathrm{H}_{\mathrm{b}}{ }^{2} \cdot \mathrm{k} . \sigma_{\mathrm{P}}$

Where: $\mathrm{k}$ (selection differential expressed in phenotypic standard deviation at $5 \%$ ) $=$ 2.06 .

The genetic advance from selection expressed as percent of grand mean was obtained as Genetic Advance $\left(R_{(X)}\right)=H_{b} \cdot k$. GCV.

This expression shows that the expected genetic advance from selection when expressed as a percent of the mean is the product of the selection differential measured in terms of the phenotypic standard deviation, the genetic coefficient of variation, and the square root of the heritability ratio (Johnson et al., 1955). Estimates of the genotypic correlation coefficients were computed according to Miller et al. (1958) and (IRRI, 2006) as presented below:

Genotypic correlation Coefficient $\mathrm{r}_{\mathrm{G}(1.2)}=$

$\sigma_{1.2} / \sqrt{ }\left(\sigma_{\mathrm{G} 1}^{2}\right)\left(\sigma_{\mathrm{G} 2}^{2}\right)$

Where $\sigma_{\mathrm{G}(1.2)}$ is the genetic covariance between two traits, $\sigma_{\mathrm{G} 1}^{2}$ is the genetic variance of the first trait and $\sigma_{\mathrm{G} 2}^{2}$ is the genetic variance of the second trait.

\section{RESULTS}

Genotype by environment interaction ( $\mathrm{G} \times \mathrm{E}$ ) was significant $(\mathrm{P}<0.05)$ for all the traits except dry matter, sucrose, total sugar and starch content 
(Table 2). Highly significant differences $(\mathrm{P}<0.01)$ were found between the sweetpotato accessions for all the traits except sucrose content which was significant at $\mathrm{P}<0.05$. The range of values for the traits, their grand mean, coefficient of variation $(\mathrm{CV})$, and standard error of mean $(\mathrm{SE})$ are presented in Table 3.

Generally, values for $\mathrm{G} x \mathrm{E}$ variance were lower than those of the genotypic variance and the error variance (Table 4). Similarly, the values for the genotypic variance were lower than those of the error variance for all the traits except betacarotene, fructose, glucose and iron content as well as harvest index, root weight and marketable root weight.

The phenotypic variance was slightly higher than the genotypic variance, except for dry matter and iron content (Table 5). The lowest and the highest values for the genotypic variance were obtained for dry matter (0.001) and beta-carotene content (21.235). A similar trend was found for the phenotypic variance, with values of dry matter and beta-carotene as 0.001 and 23.488, respectively.

The PCV values were higher than GCV values (Table 6). The PCV values ranged from $4.78 \%$ for starch content to $63.40 \%$ for marketable root weight. The GCV ranged from $4.07 \%$ for starch content to $55.35 \%$ for marketable root weight.

Broad-sense heritability ranged from 0.30 for sucrose content to 0.90 for beta-carotene content (Table 6). The expected gain from selection and genetic advance (as percent of grand mean) ranged from $0.05 \%$ (dry matter content) to 9.03 mg100 $\mathrm{g}^{-1} \mathrm{DW}$ (beta-carotene content), and $7.13 \%$ (starch content) to105.34\% (fructose content), respectively (Table 6).

Dry matter content showed positive and strong association with starch content $(r=0.71)$, but its relationship was strong and negative with beta-carotene $(r=-1.20)$, fructose $(r=-0.76)$, glucose $(r=-0.78)$, total sugar $(r=-0.77)$ and harvest index $(r=-0.69)$ (Table 7). Beta-carotene content had strong and negative association with starch content $(r=-0.61)$, but its association with glucose $(r=0.62)$, sucrose $(r=0.74)$, total sugar $(\mathrm{r}=0.56)$, iron $(\mathrm{r}=0.74)$ and zinc content $(\mathrm{r}=0.58)$ were strong and positive. Fructose and glucose showed strong and negative correlation with starch content but, strong and positive correlation

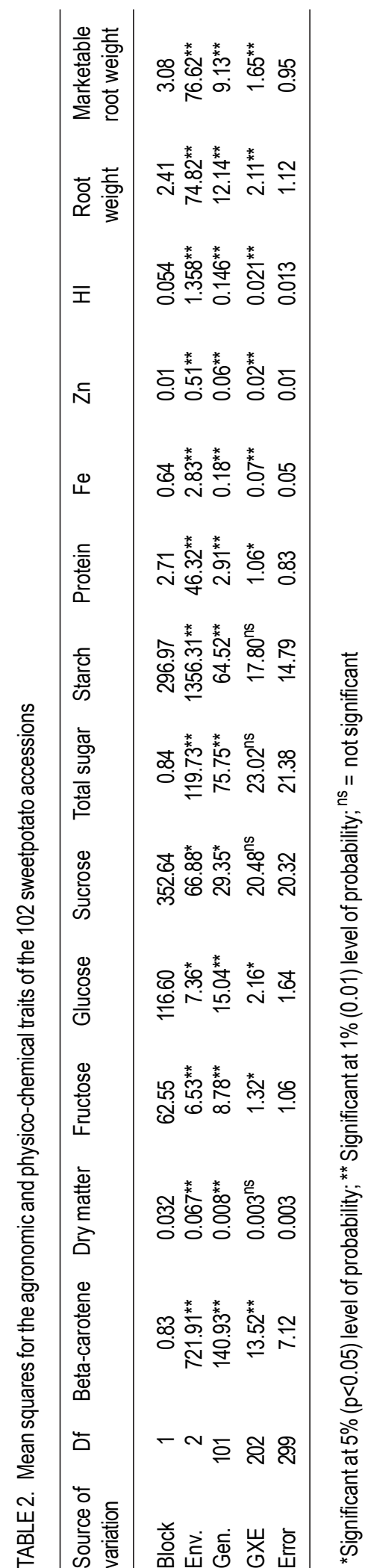


TABLE 3. Descriptive statistics for the agronomic and physico-chemical traits of the 102 sweetpotato accessions

\begin{tabular}{lrccc}
\hline Trait & \multicolumn{1}{c}{ Range } & Grand mean & CV (\%) & SE \\
\hline Dry matter & $27.00-50.00$ & 38.00 & 14.1 & 5.00 \\
Beta-carotene & $3.72-33.67$ & 11.44 & 23.3 & 2.67 \\
Fructose & $0.63-8.05$ & 2.01 & 51.2 & 1.03 \\
Glucose & $1.74-11.66$ & 3.97 & 32.3 & 1.28 \\
Sucrose & $6.77-17.15$ & 10.19 & 44.2 & 4.51 \\
Total sugars & $9.83-30.34$ & 16.46 & 28.1 & 4.62 \\
Starch & $54.72-75.64$ & 68.56 & 5.6 & 3.85 \\
Protein & $2.68-6.62$ & 4.47 & 20.4 & 0.91 \\
Iron & $1.53-2.42$ & 1.99 & 11.1 & 0.22 \\
Zinc & $0.76-1.28$ & 1.01 & 11.9 & 0.12 \\
Harvest index & $0.08-0.68$ & 0.40 & 28.0 & 0.11 \\
Root weight & $0.34-6.43$ & 2.58 & 41.0 & 1.06 \\
Marketable rootweight & $0.10-4.45$ & 2.02 & 48.3 & 0.98 \\
\hline
\end{tabular}

TABLE 4. Components of variance for agronomic and physico-chemical traits of the 102 sweetpotato accession

\begin{tabular}{lrrrr}
\hline Trait & $\sigma_{G}^{2}$ & $\sigma_{G \times L}^{2}$ & $\sigma_{E}^{2}$ & Ratio \\
& & & & $\dot{O}_{G}^{2}: \sigma_{G \times E}^{2}: \sigma_{E}^{2}$ \\
\hline Dry matter & 0.001 & 0.00 & 0.003 & $1: 0.0: 3.6$ \\
Beta-carotene & 21.235 & 3.20 & 7.120 & $1: 0.15: 0.34$ \\
Fructose & 1.243 & 0.13 & 1.060 & $1: 0.10: 0.85$ \\
Glucose & 2.147 & 0.26 & 1.640 & $1: 0.12: 0.76$ \\
Sucrose & 1.478 & 0.08 & 20.320 & $1: 0.05: 13.75$ \\
Total sugars & 8.788 & 0.82 & 21.380 & $1: 0.09: 2.43$ \\
Starch & 7.787 & 1.51 & 14.790 & $1: 0.19: 1.90$ \\
Protein & 0.308 & 0.12 & 0.830 & $1: 0.37: 2.69$ \\
Iron & 1.243 & 0.01 & 0.050 & $1: 0.55: 0.04$ \\
Zinc & 0.007 & 0.01 & 0.010 & $1: 0.75: 1.43$ \\
Harvest index & 0.022 & 0.01 & 0.010 & $1: 0.23: 0.46$ \\
Root weight & 1.672 & 0.50 & 1.120 & $1: 0.30: 0.67$ \\
Marketable rootweight & 1.247 & 0.35 & 0.950 & $1: 0.28: 0.76$ \\
\hline
\end{tabular}

with total sugar content. Similarly, negative but very strong relationship existed between total sugar and starch content $(r=-0.99)$. Harvest index had strong and positive relationship with the yield traits (Table 7).

\section{DISCUSSION}

Significant genetic diversity was observed among the accessions (Table 2) indicating the possibility of developing non-sweet high dry matter and high beta-carotene varieties simultaneously, using this population. G x E interaction is important in evaluating genotype adaptation, selection of parents and developing genotypes with improved end-product quality (Ames et al., 1999; Zhou et al., 2012). The significant $\mathrm{G} \times \mathrm{E}$ interactions observed may complicate selection for all the traits studied, except dry matter, sucrose, total sugar and starch content. G x E complicates selection by confounding the determination of true genetic values since relative performance of genotypes vary across environments. The existence of $\mathrm{G} \times \mathrm{E}$ indicates that selection should be carried out in a range of environments (Falconer and Mackay, 
TABLE 5. Estimate of genotypic and phenotypic variance for the agronomic and physico-chemical traits of the 102 sweetpotato accessions

\begin{tabular}{|c|c|c|c|}
\hline Trait & Genotypic variation & Phenotypic variation & $\begin{array}{l}\text { Ratio } \\
\sigma_{G}^{2}: \sigma_{P}^{2}\end{array}$ \\
\hline Dry matter & 0.001 & 0.001 & $1: 1.0$ \\
\hline Beta-carotene & 21.235 & 23.488 & $1: 1.1$ \\
\hline Fructose & 1.243 & 1.463 & $1: 1.2$ \\
\hline Glucose & 2.147 & 2.507 & $1: 1.2$ \\
\hline Sucrose & 1.478 & 4.892 & $1: 3.3$ \\
\hline Total sugars & 8.788 & 12.625 & $1: 1.4$ \\
\hline Starch & 7.787 & 10.753 & $1: 1.4$ \\
\hline Protein & 0.308 & 0.485 & $1: 1.6$ \\
\hline Iron & 1.243 & 0.030 & $1: 0.02$ \\
\hline Zinc & 0.007 & 0.010 & $1: 1.5$ \\
\hline Harvest index & 0.022 & 0.025 & $1: 1.1$ \\
\hline Root weight & 1.672 & 2.023 & $1: 1.2$ \\
\hline Marketable root weight & 1.247 & 1.522 & $1: 1.2$ \\
\hline
\end{tabular}

TABLE 6. Genotypic and phenotypic coefficient of variation, heritability and expected genetic advance for the traits

\begin{tabular}{lccccc}
\hline Trait & $\begin{array}{c}\text { Genotypic } \\
\text { coefficient of } \\
\text { variation }\end{array}$ & $\begin{array}{c}\text { Phenotypic } \\
\text { coefficient of } \\
\text { variation }\end{array}$ & $\begin{array}{c}\text { Heritability } \\
\left(\mathrm{H}_{\mathrm{b}}{ }_{\mathrm{b}}\right)\end{array}$ & $\begin{array}{c}\text { Expected selection } \\
\text { gain }(\mathrm{R})\end{array}$ & $\begin{array}{c}\text { Expected selection } \\
\text { gain }(\mathrm{R} \% \text { of mean) }\end{array}$ \\
\hline Dry matter & 7.60 & 9.61 & 0.63 & 0.05 & 12.37 \\
Beta-carotene & 40.28 & 42.36 & 0.90 & 9.03 & 78.90 \\
Fructose & 55.48 & 60.18 & 0.85 & 2.12 & 105.34 \\
Glucose & 36.91 & 39.88 & 0.86 & 2.79 & 70.35 \\
Sucrose & 11.93 & 21.70 & 0.30 & 1.38 & 13.51 \\
Total sugars & 18.01 & 21.59 & 0.70 & 5.10 & 30.95 \\
Starch & 4.07 & 4.78 & 0.72 & 4.89 & 7.13 \\
Protein & 12.46 & 15.58 & 0.64 & 0.91 & 20.40 \\
Iron & 6.80 & 8.70 & 0.61 & 0.22 & 10.96 \\
Zinc & 8.08 & 9.90 & 0.65 & 0.14 & 13.60 \\
Harvest index & 36.80 & 39.53 & 0.84 & 0.27 & 68.40 \\
Rootweight & 50.13 & 55.13 & 0.83 & 2.42 & 93.83 \\
Marketable root weight & 55.35 & 63.40 & 0.76 & 2.01 & 99.40 \\
\hline
\end{tabular}

1996). This is because progress from selection is realised only when genotypic effects can be separated from environmental effects (Miller $e t$ al., 1958). Beta-carotene content may be an exception because the orange-fleshed colour associated with it makes it easy to select.

Differences in genotypic and phenotypic variances (Table 5) may be attributed to environmental effects. It is essential that germplasm testing procedures are designed to maximise the genetic effects relative to the environmental and interaction effects. Information on the relative magnitudes of the different sources of variance observed in this study (Table 4) provides a guide towards maximising the genetic effects relative to the environmental and interaction effects. The magnitudes of $\mathrm{G} \times \mathrm{E}$ interaction variances were smaller than the error variances (Table 4), implying that the accessions were tested in 
adequate sample environments. However, a large number of replicates may be required for traits with lower genetic variance than the error variance (root dry matter, sucrose, total sugar, starch, protein and zinc content) to enhance the optimisation of their genetic effects.

The trends for the PVC and the GVC values (Table 6) were in agreement with the results reported for Solanum anguivi (Denton and Nwangburuka, 2011), Corchorus olitorius (Nwangburuka and Denton, 2012), Triticale (Kumar et al., 1985) and oat (Prasad et al., 1981). The observed trend between PVC and GVC could be attributed to environmental effects (Denton and Nwangburuka, 2011). This is because variance of phenotype is due to genotypic and environmental factors combined. High PCV and GCV values which were detected for marketable root weight, root weight, fructose content, betacarotene content, glucose content, harvest index, and total sugar content suggest that these traits accounted for the highest variation observed in the sweetpotato accessions. This means that the sweetpotato accessions showed high diversity for these traits which could lead to higher selection precision for superior accessions for the traits.

GCV provides a measure for comparing the genetic variability present in various quantitative traits. However, it is not possible to estimate heritable variation with the help of the GCV alone (Prasad et al., 1981). The GCV together with heritability estimates would give the best picture of the amount of advance to be expected from selection (Burton, 1952). Heritability indicates the effectiveness with which selection of genotypes can be based on phenotypic performance (Johnson et al., 1955; Nwangburuka et al., 2012; Mwije et al., 2014). In this study, broad-sense heritability estimates varied from medium to high, with the exception of sucrose content which had low heritability (Table 6).

Traits with medium to high heritability are influenced by additive gene effects (Denton and Nwangburuka, 2011). This suggests that selection based on phenotype will be effective. However, the heritability value in itself does not provide an indication of the amount of genetic progress that would result from selecting the best individuals (Johnson et al., 1955). The utility of estimates of 
heritability is increased when they are used in conjunction with the selection differential (the amount that the mean of the selected lines exceeds the mean of the entire population), since genetic advance is commonly predicted as the product of the heritability and the selection differential.

Prediction of the response of an individual to selection is more reliable when GCV, broad-sense heritability and genetic advance are combined (Ghandi et al., 1964; Ibrahim and Hussein, 2006). The predicted improvement over the means for this population is above $10 \%$ and up to $105 \%$ for all the traits, except starch content (7.13\%). Miller et al. (1958), observed $13-15 \%$ response to selection for lint yield of upland cotton, and noted that it was particularly encouraging. This suggests that sufficient useful genetic variation is present in this population that could be used to provide substantial improvement through the selection of superior accessions. The type of gene action operating is also critical since the expected amount of superiority will be realised in subsequent generations only if all of the genetic effects are additive (Miller et al., 1958; Falconer and Mackay, 1996). Conversely, non-additive effects (epistasis, dominance, and interactions) may decrease the amount of genotypic superiority passed on. It is, therefore, important to seek additional information concerning the nature of gene action in order to buttress this point in sweetpotato.

Genetic relationships between traits (Table 7) may result from pleiotropic gene effects, linkage of two genes, linkage disequilibrium and epistatic effects of different genes or environmental influences (Falconer and Mackay, 1996). Except for the very high $(>1)$ values observed for dry matter and beta-carotene content (-1.2), sucrose and total sugar content (1.09), sucrose and iron content (1.07), and sucrose and zinc content (1.15), the values for the genetic correlation coefficient were in agreement with those reported by Grüneberg et al. (2009). Denton and Nwangburuka (2011) also reported genotypic correlation coefficients greater than one in a study on Solanum anguivi. A similar observation was made by Nwangburuka and Denton (2012) for character association on leaf Corchorous olitorius.
The correlations observed are thus population specific because the interrelationships might be quite different in populations in which different gene associations exist in the parental lines (Miller et al., 1958). The differences observed could also be attributed to the variations in the mean values of the characters under study which are at levels different from the other studies. The strong positive association observed between dry matter content and starch content, and the strong negative relationship found for sugar content and dry matter and starch content indicates that it is possible to develop non-sweet high dry matter sweetpotato varieties which are the preferred sweetpotatoes for most Ghanaians (Baafi et al., 2015; Baafi et al., 2016). A similar observation was made by Grüneberg et al. (2009), who reported that development of non-sweet sweetpotato varieties should not be too difficult. However, developing non-sweet, high dry matter and high betacarotene sweetpotato varieties could be challenging due to the strong negative association between dry matter content and betacarotene content, and the positive association between beta-carotene content and sugar content. Breeding for such cultivars may require many cycles of selection and hybridisation to break genetic linkages associated with the traits. However, beta-carotene is controlled by a limited number of genes (Oduro, 2013; Baafi, 2014) and should be easy to manipulate. The results also showed that dry matter content, sugar content and most of the physico-chemical traits (except protein) may indirectly be selected using betacarotene content (the orange-fleshed colour).

\section{CONCLUSION}

Significant genetic diversity was established between the accessions studied for dry matter, beta-carotene and sugar content. The relative magnitude of the $\mathrm{G} \times \mathrm{E}$ variance to the other variances indicates high potential for progress from selection since the superior accessions in the population can be readily identified. This means that sufficient useful genetic variation is present in the population which may be exploited to provide for substantial amount of improvement through selection of superior accessions. High 
heritability coupled with the high gains expected indicate high breeding value and mostly additive genetic effects. This suggests that selection can be effective for these traits. The strong negative association between dry matter content and sugar content indicates that it is feasible to develop non-sweet high dry matter sweetpotato cultivars. However, developing non-sweet, high dry matter varieties with a high beta-carotene content may require many cycles of selection.

\section{ACKNOWLEDGEMENT}

The study was supported by the Alliance for a Green Revolution in Africa (AGRA) through the West Africa Centre for Crop Improvement (WACCI), University of Ghana and the International Potato Centre through the Sweetpotato Action for Security and Health in Africa (SASHA) Project.

\section{REFERENCES}

Ames, N.P., Clarke, J.M., Marchylo, B.A., Dexter, J.E. and Woods, S.M. 1999. Effect of environment and genotype on drurum wheat gluten strenght and paster viscoelasticity. Cereal Chem. 76:582-586

Baafi, E. 2014. Development of end-user preferred sweetpotato varieties in Ghana. $\mathrm{PhD}$ thesis. West Africa Centre for Crop Improvement (WACCI), University of Ghana, Legon, Ghana.

Baafi, E., Manu-Aduening, J., Carey, E.E., Ofori, K., Blay, E.T. and Gracen, V.E. 2015. Constraints and breeding priorities for increased sweetpotato utilisation in Ghana. Sustainable Agriculture Research 4(4) 1 16. ISSN 1927-050X E-ISSN 1927-0518. doi:10.5539/sar.v4n4p1. URL: http:// dx.doi.org/10.5539/sar.v4n4p1.

Baafi, E., Manu-Aduening, J., Gracen, V.E., Ofori, K., Carey, E.E. and Blay, E.T. 2016. Development of end-user preferred sweetpotato varieties. Journal of Agricultural Science 8(2): 57-73. ISSN 19169752. E-ISSN 1916-9760. doi:10.5539/ jas.V8n2p57. URL:http://dx.doi.Org/10.5539/ jas.V8n2p57.
Bouvelle-Benjamin, A.C. 2007. Sweetpotato: A review of its past, present and future role in human nutrition. California, USA: Elsevier Academic Press. pp. 3-48.

Burton, G.W. 1952. Quantitative inheritance in grasses. Proceedings of the $6^{\text {th }}$ International grassland congress, Aug. 17-23, Pennsylvania State College, USA. pp. 297-283.

Denton, O.A. and Nwangburuka, C.C. 2011. Heritability, genetic advance and character association in six yield related characters of solanum anguivi. Asian Journal of Agricultural Research 5: 201-207.

Devi, M., Kumar, K.I. and Niranjana, R.F. 2014. Biology of sweetpotato weevil, Cylas formicarious $f$. on sweetpotato. Journal of Entomological Research 38(1) : 53-57. ISSN:0378-9519.

Ekanayake, I.J., Malagamba, P. and Midmore, D.J. 1990. Effect of water stress on yield indices of sweetpotatoes. In: Howeler, R.H.(Ed.). Proceedings $8^{\text {th }}$ symposium of the International Society for Tropical Root Crops. Bangkok, Thailand. 724pp.

Falconer, D.S. and Mackay, T.F.C. 1996. Introduction to quantitative genetics. 4th edn., Longman, England.

Gasura, E., Mashingaidze, A.B. and Mukasa, S.B. 2008. Genetic variability for tuber yield, quality, and virus disease complex in Uganda sweetpotato germplasm African Crop Science Journal 16: 147-160.

Genstat, 2007. For windows release 9.2.0.152. Genstat-ninth edition@2007, Lowes Agricultural Trust.

Ghandi, S.H., Sanghai, A.K., Nathawat, K.S. and Bhatnagar, M.P. 1964. Genotypic variability and correlation coefficient to grain yield and few other quantitative characters in india wheat. Indian J. Genet. Breed. 24:1-8.

Grüneberg, W., Mwanga, R., Andrade, M. and Dapaah, H. 2009. Sweetpotato breeding. In: Unleashing the potential of sweetpotato in Sub-Saharan Africa: Current challenges and way forward. Andrade, M., Barker, I., Dapaah, H., Elliot, H., Fuentes, S., Grüneberg, W., Kapinga, R., Kroschel, J., Labarta, R., Lemaga, B., Loechl, C., Low, J., Lynam, J., Mwanga, R., Ortiz, O., Oswald, A. and Thiele, G. (Eds.). 
Lima, Peru: International Potato Center (CIP). Working Paper 2009-1. pp. 1- 42.

Ibrahim, M.M. and Hussein, R.M. 2006. Variability, heritability and genetic advance in some genotypes of roselle (Hibiscus sabdariffa L.). World J. Agric. Sci. 2:340-345.

IRRI, 2006. International rice Research Institute : Welcome to irr's rice breeding course. Irritraining@irri.Org < mailto:\%20irritraining @ irri.Org >

Johnson, H.W., Robinson, H.F. and Comstock, R.E. 1955. Estimates of genetic and environmental variability in soybean. Agron. J., 47:314-318.

Kumar, A., Misra, S.C., Singh, Y.P. and Chauhan, B.P.S. 1985. Variability and correlation studies in triticale. J. Maharashtra Agric. Univ., 10: 273-275.

Lebot, V. 2010. Sweet potato. In: Bradshaw, J.E. (Ed.), root and tuber Crops, handbook of Plant breeding 7, 97. Doi 10.1007/978-0-387-927657_3, (c) springer Science+business media, 1lc 2010.

Miller, P.A., Williams, J.C., Robinson, H.F. and Comstock, R.E. 1958. Estimates of genotypic and environmental variances and covariances in upland cotton and their implications in selection. Agron. J., 50: 126-131.

Missah, A. and Kissiedu, A.F.K. 1994. Effect of time of harvesting on the yield and pest incidence of two sweetpotato varieties in the forest zone of Ghana. In proc $5^{\text {th }}$ ISTRC AB, 1994., 276-280.

Mwije, A., Mukasa, S.B., Gibson, P. and Kyamanywa, S. 2014. Heritability analysis of putative drought adaptation traits in sweetpotato. African Crop Science Journal 22 (1): 79-87. ISSN 1021-9730/2014.

Nwangburuka, C.C., Denton1, O.A., Kehinde, O.B., Ojo, D.K. and Popoola, A.R. 2012. Genetic variability and heritability in cultivated okra [Abelmoschus esculentus (L.) moench]. Spanish Journal of Agricultural Research 10(1): 123-129. ISSN: 1695-971-x. eISSN: 2171-9292. doi: http://dx.doi.Org/ 10.5424/sjar/2012101-021-11. Www.Inia.Es/ sjar.
Nwangburuka, C.C. and Denton, O.A. 2012. Heritability, character association and genetic advance in six agronomic and yield related characters in leaf corchorus olitorius. International Journal of Agricultural Research 7: 367-375.

Oduro, V. 2013. Genetic control of sugars, dry matter and beta-carotene in sweetpotato (Ipomoea batatas [L.] Lam). PhD thesis. West Africa Centre for Crop Improvement (WACCI), University of Ghana, Legon, Ghana.

Prasad, S.R., Prakash, R., Sharma, C.M. and Haque, M.F. 1981. Genotypic and phenotypic variability in quantitative characters in oat. Indian J. Agric. Sci., 54: 480-482.

Steel, R.G.D. and Torrie, T.H. 1980. Principles and procedures of statistics: A biometrical approach. $2^{\text {nd }}$ Edn., mcgraw Hill book co. Inc., New York.

Tumwegamire, S., Kapinga, R., Rubaihayo, P.R., Labonte, D.R., Grüneberg, W.J., Burgos, G., Zum Felde, T., Carpio, R., Pawelzik, E. and Mwanga, R.O.M. 2011. Starch, sucrose, âcarotene, iron, zinc, calcium, and magnesium in East African sweetpotato [Ipomoea batatas (L.) Lam] germplasm. HortScience 46: 348-357.

Van Hal, M. 2000. Quality of sweetpotato flour during processing and storage. Food Review International 16:1-37.

Warammboi, J.G., Dennien, S., Gidley, M.J. and Sopade, P. 2011. Characterization of sweetpotato from papua New guinea and Australia: Physicochemical, pasting and gelatinisation properties. Food Chem, 126: 1759-1770.

Watson, I. and Dallwitz, M.J. 2000. The families of flowering plants. Descriptors, illustrations, identification and information retrieval. Version: 14 ${ }^{\text {th }}$ December, 2000. http:// www.Biodiversity.Uno.Edu/delta/.

Zhou, M., Joshi, V.S. and Maritz, T. 2012. Trends and implications of genotype by environment interaction in south African sugarcane breeding. Journal of Crop Improvement 26: 163-176. http://dx.doi.org/10.1080/ 15427528.2011.622429. 